\title{
The Effect of Gas Production, Utilization, and Flaring on the Economic Growth of Nigeria
}

\author{
Ikechukwu A. Diugwu ${ }^{1}$, Mukalia A. Ijaiya ${ }^{2}$, Musa Mohammed ${ }^{1}$, Ashem E. Egila ${ }^{1}$ \\ ${ }^{1}$ Project Management Technology Department, Federal University of Technology, Minna, Nigeria; ${ }^{2}$ Department of Entrepreneurship \\ and Business Studies, Federal University of Technology, Minna, Nigeria. \\ Email: i.diugwu@aim.com, i.diugwu@futminna.edu.ng
}

Received May $7^{\text {th }}, 2013$; revised June $16^{\text {th }}, 2013$; accepted June $29^{\text {th }}, 2013$

Copyright (C) 2013 Ikechukwu A. Diugwu et al. This is an open access article distributed under the Creative Commons Attribution License, which permits unrestricted use, distribution, and reproduction in any medium, provided the original work is properly cited.

\begin{abstract}
The extent to which a country develops is anchored around its resources; and this is evidenced in how the revenue derived from natural resources (especially the oil and gas industries) has influenced national development strategies. This notwithstanding, the existence of natural resources does not always translate to development, as these often times lead to complacency and mismanagement; Nigeria may have suffered from this. This paper establishes the impact of gas production, utilization, and flaring on the estimated monetary value of the goods and services produced in Nigeria (GDP), using multiple linear regression analysis. The result shows that while gas utilization has a positive impact on the nation's GDP, gas production and flaring are negatively associated with GDP. The paper concludes that for these to positively stimulate economic growth, there is need to invest more in infrastructure in the industry, and review the regulatory framework guiding operations of the oil and gas industry.
\end{abstract}

Keywords: Natural Gas; Associated Gas; Flaring; Petroleum; Economy; GDP; Nigeria

\section{Introduction}

The strategies of many countries are often woven around, and influenced by available resources such as mineral deposits, oil and natural gas. In view of this, [1] concludes that the presence of natural resources (especially oil and gas) plays an important role in national development strategy. This notwithstanding, the existence of natural resources does not always translate to development - a situation that may have influenced certain views. Michael Ross [2], for example, propounded the resource curse theory, a theory which perhaps substantiates the view that while growth rates in resource-rich countries seem stagnated, there are signs of rapid growth in resource-poor countries [3-5]. Although many reasons have been adduced for this [6-8], the authors of this paper identify with the view that the inability of resource industries to stimulate growth cannot be totally divorced from the predominance of the resource extraction Industry by foreign multinationals who choose to repatriate their profits instead of (re)investing them locally $[9,10]$. There is also a suggestion of a positive association between resource extraction and breakdown in law and order $[2,11]$. This may, perhaps be the reason why in Nigeria, no meaningful progress has been made in reducing the frequency and level of oil spill incidences, poor remediation and clean up of the environment, illegal oil exploration and refining, among others.

In spite of these observations, in Nigeria for instance, there seems to be a determination to correct the perceived imbalances in the management of the oil and gas sector. For example, rather than allow the flaring of associated gas, the Nigerian National Petroleum Corporation (NNPC) hopes to transform Nigeria into a leading Liquefied Natural Gas (LNG) producing and utilization nation [12] by commercializing Nigeria's abundant gas reserves and promoting a viable LNG industry. The comment by Mrs Diezani Alison-Madueke (Nigeria's Minister of Petroleum Resources), that Nigeria intends to reduce flared gas from the current $7 \%$ to $2 \%$ by 2017 [13] corroborates this desire. This is a laudable vision as better exploitation of natural gas resources, especially those under utilized in West Africa, is seen as a significant way to satisfy the world's increasing natural gas demand, which has been projected to grow by $1.9 \%$ annually, reaching 4700 billion cubic metres (BCM) in 2030, and account for $24.4 \%$ of expected energy consumption $[14,15]$. However, this vision can only be realized if established management principles and procedures are adopted. First, those 
assets and capabilities that could enhance the efficiency and effectiveness of adopted development strategies need to be identified [16]. This is because some resources may actually prevent some valuable strategies from being conceived and implemented [17]. Michael Porter's works [18-21] are good sources of information on the relationship between resources and sustainable development/ competitive advantage.

In view of the above, this paper intends to contribute towards the oil and gas development strategy of the Federal Government of Nigeria through a systematic analysis of gas production, utilization, and flaring. It shall go further to make a case for better regulation and management of the gas sector of the oil and gas industry as a way of maximizing its potentials. Although, there have been earlier studies of gas flaring in Nigeria, they are fundamentally different from this. For instance, [22] attempted an assessment of the economic cost of gas flaring in Nigeria between 1965 and 2008, but did not quantify this in monetary terms, perhaps the only language known to public (political) office holders in Nigeria. Another study by [23] looked at the contributions of major oil companies to the overall gas flaring activity in Nigeria, while [24] on the other hand, studied the relationship among gas flaring, transportation and sustainable energy development in the Niger-Delta region of Nigeria.

\section{Literature Review}

\subsection{Natural Gas Resource in Nigeria}

Nigeria boasts of substantial natural gas reserve that is estimated to be even greater than her oil reserve [25]. It could be seen from Table 1 below that as at the end of

Table 1. Nigeria's natural gas proved reserves and production at the end of 2011.

\begin{tabular}{cccccc}
\hline & \multicolumn{3}{c}{ Proved reserves } & \multicolumn{2}{c}{ Gas production } \\
\cline { 2 - 6 } & $\begin{array}{c}\text { Trillion } \\
\text { cubic metres }\end{array}$ & $\begin{array}{c}\text { Share } \\
\text { of total }\end{array}$ & $\begin{array}{c}R / P \\
\text { ratio }\end{array}$ & $\begin{array}{c}\text { Billion cubic } \\
\text { metres (bcm) }\end{array}$ & $\begin{array}{c}\text { Share of } \\
\text { total }\end{array}$ \\
\hline Algeria & 4.5 & $2.2 \%$ & 57.7 & 78.0 & $2.4 \%$ \\
Egypt & 2.2 & $1.1 \%$ & 35.7 & 61.3 & $1.9 \%$ \\
Libya & 1.5 & $0.7 \%$ & $*$ & 4.1 & $0.1 \%$ \\
Nigeria & 5.1 & $2.5 \%$ & $*$ & 39.9 & $1.2 \%$ \\
Other Africa & 1.2 & $0.6 \%$ & 63.4 & 19.4 & $0.6 \%$ \\
Total Africa & 14.5 & $7.0 \%$ & 71.7 & 202.7 & $6.2 \%$ \\
Total World & 280.4 & $100.0 \%$ & 63.6 & 3276.2 & $100 \%$ \\
\hline
\end{tabular}

*More than 100 years; Notes: Proved reserves of oil - Generally taken to be those quantities that geological and engineering information indicates with reasonable certainty can be recovered in the future from known reservoirs under existing economic and operating conditions; Reserves-to-production $(\mathrm{R} / \mathrm{P})$ ratio- If the reserves remaining at the end of any year are divided by the production in that year, the result is the length of time that those remaining reserves would last if production were to continue at that rate. Source: [26].
2011, the proved natural gas reserve of Nigeria is estimated to be about 5.1 trillion cubic metres; about $2.5 \%$ of the 208.4 trillion cubic metres of world proven natural gas reserves, and reserves-to-production $(\mathrm{R} / \mathrm{P})$ ratio of more than 100 years [26].

In spite of the estimated gas potentials, both anecdotal and empirical evidences suggest that the potentials from the level of resource endowment have not been maximally exploited. It could be seen from the data presented in Table 1 that while Nigeria has the highest proved gas reserves in Africa, it is placed a distant third in terms of gas production. The inability to maximise our gas reserve potentials could partly be blamed on gas flaring activity. Gas flaring, which is the combustion of associated gas produced with crude oil or from gas fields [27], has been discussed extensively in existing literature. Associated gas is the raw natural gas (usually a mixture of methane and other hydrocarbons) that emerges from oil wells [28].

\subsection{Gas flaring in Nigeria: A Comparison with Global Trend}

There seems to be a level of uncertainty about the actual volume of gas flared globally. This is perhaps due to lack of monitoring equipment and limited oversight [29], as well as the inability of many countries to publicly report gas flaring volumes [30].

Farina [29], for instance, suggests a global annual gas flare volume of 120 to $200 \mathrm{BCM}$, while [31] gives a figure between 140 to $170 \mathrm{BCM}$. Again, GGFR [32] estimates that about $146 \mathrm{BCM}$ of natural gas is flared globally every year, GGFR [33] notes that in 2011, a lower volume of $140 \mathrm{BCM}$ of natural gas was flared globally. Figure 1 below shows the volume of gas flared globally from 1994 to 2011 as estimated by the Defense Meteorological Satellite Program (DMSP) [34].

A significant inference to be drawn from [34] is that gas glaring is not evenly spread but concentrated in a small number of countries; with the top two gas flaring countries (Russia and Nigeria) accounting for about $40 \%$ of global gas flare and the top twenty countries account-

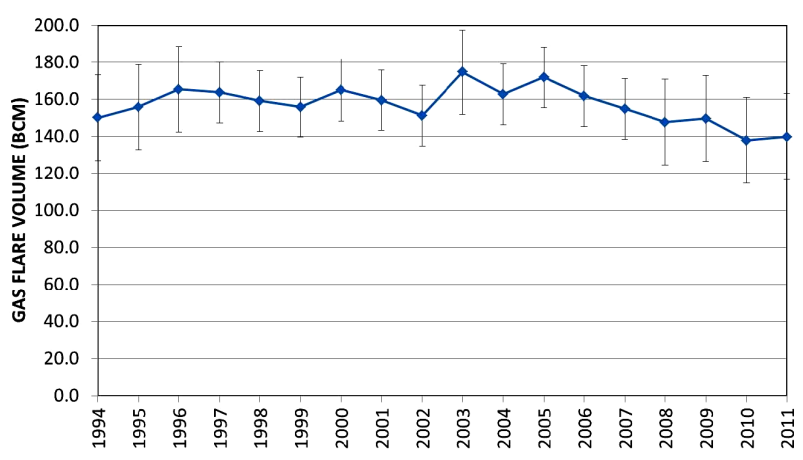

Figure 1. DMSP global estimates of flared gas volume (Source: [34]). 
ing for about $85 \%$ of total global gas flare [31].

The impression created by the figure above confirms the view that Nigeria has, perhaps, one of the worst rates of gas flaring in the world [35], having flared about $76 \%$ of her natural gas in 2002 [36], and $60 \%$ in 2006 [37]. These flare data are an accumulation of the 2.5 billion cubic feet of gas that is flared per day, amounting to an estimated 2.5 billion US dollars yearly revenue loss [38]. These data can be placed within the context of Figure 2 below which shows Nigeria's natural gas production, utilization and flaring trend between 2002 and 2011 .

\subsection{Major Motivators of Gas Flaring}

While gas flaring could be carried out as a precautionary measure on oil exploration and production fields/platforms, unregulated flaring could have disastrous consequences. Gas flaring occurs due to several reasons. In the views of [40], it could be due to safety reasons wherein gas is flared in order to relief pressure on the system in cases of emergency or during maintenance; or as part of quality assurance procedure during well tests or start-ups of new installations, where gas is flared until gas with the required properties (for transportation or re-use) is obtained. Reference [31] believes that a major reason for continued gas flaring is the dearth of infrastructure which makes it impossible to commoditize the gas. This category of continuous flaring represents the largest quantities. Specifically with respect to Nigeria, [41] suggests that gas flaring has continued because of limited number of reservoirs suitable for gas reinjection/storage, the cost of developing major and inter-connecting network of gas pipelines, low technological and industrial base for energy consumption in the country, limited regional and international gas market, as well as inadequate fiscal and gas pricing policies to encourage investment. It has been noted that the dearth of infrastructure results in the flaring of approximately $76 \%$ of associated gas in Nigeria, compared $8 \%$ in Alberta, Canada [42,43]. Some other sources present an economic perspective to gas flaring, observing that it oil companies may find it cheaper to pay fines (often viewed as insignificant by the oil companies) that may be levied on them for flaring gas, than finance the re-injection of the gas back into the oil wells [44].

\subsection{Economic and Environmental Implications of Gas Flaring}

There are no doubts about the environmental, health and economic implications of gas flaring. An instance of this is the observation by [29] that gas flaring leads to environmental degradation, which impacts significantly on local populations, with a high likelihood of loss of livelihood and severe health issues. The soot and carbon monoxide resulting from the incomplete combustion of associated natural gas contribute to air pollution [45]. Again, according to [28], associated gas flaring releases carbon dioxide $\left(\mathrm{CO}_{2}\right)$ and carbon monoxide $(\mathrm{CO})$, alongside other pollutants such as volatile organic compounds (VOC) into the atmosphere. And these pollutants lead to premature death, respiratory illnesses, cancers, asthma attacks among others [46].

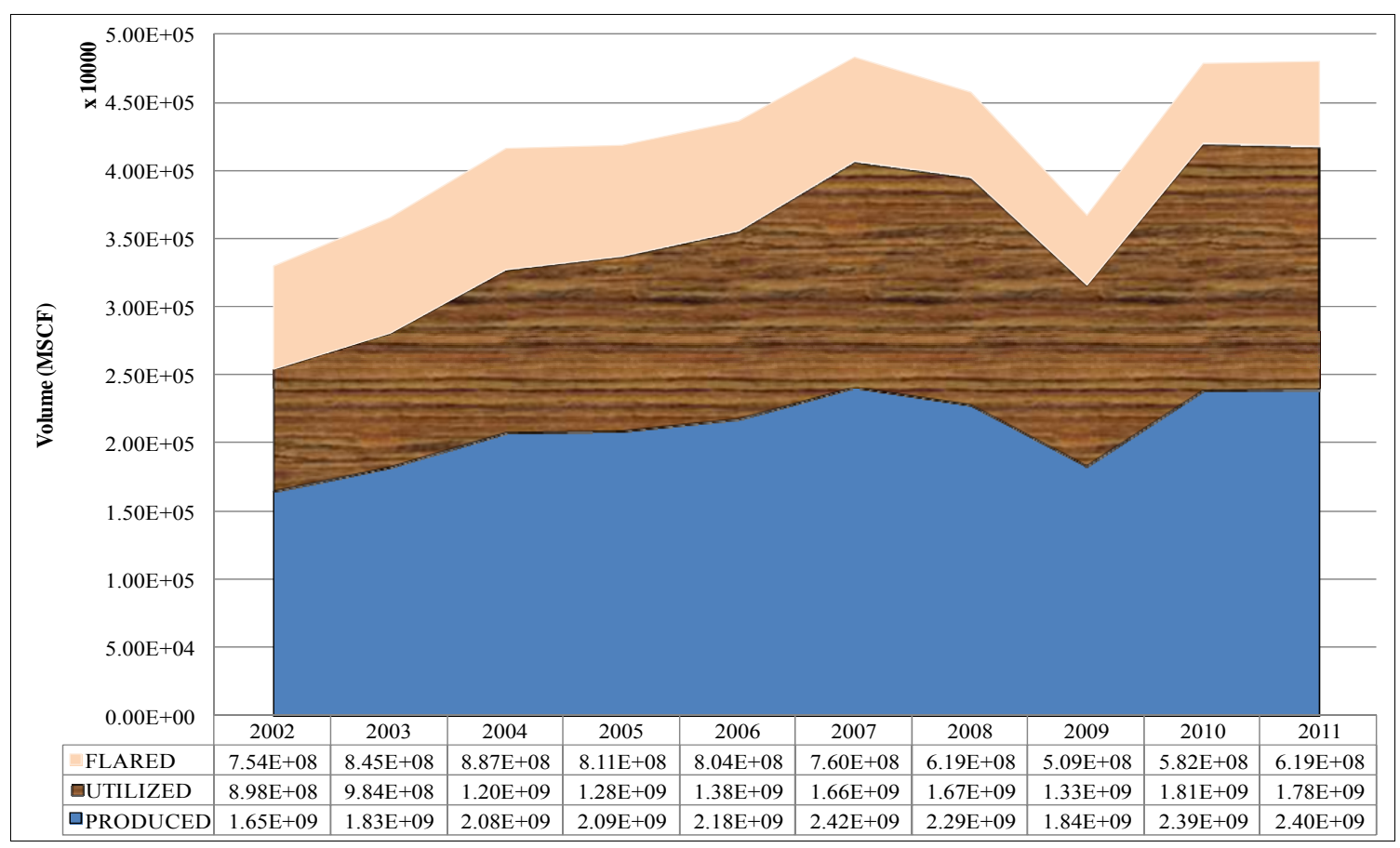

Figure 2. Ten year trend of natural gas utilization, production, and flaring in Nigeria (Source: [39]). 
It is estimated that about $\$ 3$ billion is lost annually through gas flaring in sub-Saharan Africa [47]. Equally, the energy resource wasted in Nigeria alone is equivalent to $45 \%$ of the energy requirements of France [48]. The World Bank [49] highlights how the volume of flared natural gas could help boost electricity generation. Gas flaring contributes to global warming by emitting greenhouse gas and carbon dioxide equivalent $\left(\mathrm{CO}_{2} \mathrm{e}\right)$ into the atmosphere $[29,31,50]$. In Nigeria, an estimated 35 million and 12 million tons of carbon dioxide $\left(\mathrm{CO}_{2}\right)$ and methane $\left(\mathrm{CH}_{4}\right)$ respectively, acknowledged as global warming inducing substances, are released into the atmosphere $[42,51]$.

\subsection{Utilization of Flared Gas}

The above statistics and their attendant consequences notwithstanding, the argument has not been whether associated gas should be flared at all, but rather how best to effectively utilize associated natural gas and or regulate its disposal. There is a business case for proper harnessing and adequate utilization of associated natural gas, as it can be a source of huge foreign exchange [52]. Offshore associated gas could be treated, recovered and economically utilized in power generation [53]. This view is supported by the outcome of the study by [54] which suggests that substantial amount of money could be saved if conventional fuel and energy were to be substituted with natural gas. This could also reduce the level of loss reported by [47].

\section{Materials and Method}

\subsection{Data Sources}

The results presented here were derived from data obtained from secondary sources. The data on gross domestic product (GDP), and the capital stock $(\mathrm{K})$ measured by the gross capital formation (GCF) were obtained from the National Bureau of Statistics data portal. The data used for labour stock (L) were the total labour force data of Nigeria, obtained from the World Banks World Development Index (WDI) database. Nigeria's gas production, utilization, and flaring data were obtained from the Nigeria National Petroleum Corporation's (NNPC) statistical bulletins.

\subsection{Model Specification}

This study assesses the influence of the volume of gas flared on the economic growth of Nigeria (GDP in this instance) using an econometric analysis based on the Cobb-Douglas non-linear production function built around gas production and utilization. The model is thus used in estimating the impact of these components on Nigeria's economic growth. The model is an independent and additive one, relating economic growth with components of gas production (GASP) and gas utilization (GASU). The essence of this model is to determine, simultaneously, the relative weights of each componentgas production and gas utilization - on improved economic growth in Nigeria, using gross domestic product (GDP) as proxy. Emphasis is placed on whether gas production and utilization has a significant impact on economic growth of Nigeria. Against this background, the model is formulated using the Cobb and Douglas [55] version of the production function, which according to [56] is popular in applied research because it is easier to handle mathematically. The production function in its general form is purely technological in relation to quantities of inputs and outputs. The production function in the neo-classical growth model is given as:

$$
Q=f(K, L)
$$

where $Q=$ output (amount); $K=$ capital input; $L=$ Labour input.

The above was expanded and transformed by [55] to yield the Cobb-Douglas production function shown below:

$$
Q=A K^{\alpha} L^{\beta} \mu .
$$

Disembodying capital from Equation (2) above yields;

$$
Q=A K_{1}^{\alpha 1} K_{2}^{\alpha 2} L^{\beta} \mu,
$$

where $Q$ is the output; $A$ is the technical efficiency (or coefficient of production); $K_{1}$ is the gas production and utilization; $K_{2}$ is the capital inputs proxied by the nation's gross capital formation.

Disaggregating Equation (3) above yields

$$
Q=A K_{11}^{\alpha 11} K_{12}^{\alpha 12} K_{13}^{\alpha 13} K_{2}^{\alpha 2} L^{\beta} \mu .
$$

In view of the fact that the Cobb-Douglas production function exhibits a non-linear relationship, it would be more appropriate to work with the logarithms of the variables during the transformation process of estimation.

$$
\therefore \ln Q=\ln A+\alpha_{11} K_{11}+\alpha_{12} K_{12}+\alpha_{13} K_{13}+\alpha_{2} \ln K_{2}+\beta \ln L+\mu
$$

where $\ln Q=\log$ output proxied by the nation's GDP; $\ln A$ is the log of technical efficiency (or coefficient of production); $K_{11}$ is the volume of gas produced; $K_{12}$ is the volume of gas utilised; $K_{13}$ is the volume of gas flared; $\ln K_{2}$ is the $\log$ of capital inputs; $\ln L$ is the $\log$ of labour input; $\alpha_{11}-\alpha_{13}$ are the estimation parameters associated with the influence of gas production and utilisation on economic growth in Nigeria; $\alpha_{2}$ and $\beta$ are the estimation parameters associated with the influence of capital and labour on economic growth in Nigeria; $\mu$ is the disturbance term.

The a-priori expectation regarding the relationship 
among the independent variables $\left(K_{11}, K_{12}, K_{13}, K_{2}, L\right)$ and the dependent variable (GDP) is that

$K_{11}>0, K_{12}>0, K_{13}<0, K_{2}>0, L>0$. That is, all coefficients, with the exception of gas flaring, are expected to positively impact on the economic performance of Nigeria.

In estimating the model, a multiple regression analysis is used in order to reflect the explanatory nature of the variance; while verification of the validity of the model was based on two major evaluation criteria:

1) The a-priori expectation criterion which is based on the signs and magnitude of the coefficients of the variables under investigation, and.

2) Statistical criteria which are based on statistical theory, which in other records is referred to as the first order least square (OLS) consisting of $R$-square $\left(R^{2}\right)$, F-statistic and $t$-test. The $R^{2}$ is concerned with the overall explanatory power of the analysis and the $t$-test is used to test the significant contribution of the independent variable on the dependent variables [57, $58]$.

\section{Results and Discussion}

The summary of the result of the regression analysis carried is presented in Table $\mathbf{2}$ (see Appendices $\mathbf{1}$ and $\mathbf{2}$ for details of data used and result obtained respectively).

The regression result with an $R^{2}$ value of 0.99 , shows a good fit, suggestive that $99 \%$ variation in the dependent (endogenous) variable (GDP) is explained by the explanatory (exogenous) variables (gas produced, gas utilized and gas flared), while the error term takes care of the remaining $1 \%$ (which are the variables in the study that cannot be included in the model because of certain qualitative features). The computed F-statistic value of 59.36, which is greater than the tabulated F-statistic value of 2.58 at $5 \%$ level of significance, indicates a negative relationship between economic growth and gas flaring in Nigeria. Furthermore, a Prob (F-statistic) value of 0.00763 shows that the regression equation has some degree of validity in fitting the data; in order words, the independent (exogenous) variables are not purely random with respect to the dependent (endogenous) variables.

A consideration of the coefficients and associated $t$ values shown in Table 2 shows an agreement with the a-priori expectations in all the variables except that of gas produced (GASP) and capital (K). It could then be concluded that gas flaring has a negative impact on the economic growth of Nigeria. Again, gas production in Nigeria could be said to be statistically insignificant to her economic growth. This outcome is not surprising because, as pointed out earlier, although Nigeria's 5.1 trillion cubic metres of proved gas reserves is the highest in Africa, she produces only 39.9 billion cubic metres of
Table 2. Summary of regression result.

\begin{tabular}{ccc}
\hline Explanatory variable & Coefficient & $\boldsymbol{t}_{\text {-value }}{ }^{*}$ \\
\hline Intercept $(\mathrm{C})$ & -2.2622501 & -0.141347 \\
Gas produced $\left(K_{11}\right)$ & -0.072858 & -3.190343 \\
Gas utilized $\left(K_{12}\right)$ & 0.569982 & 5.737055 \\
Gas flared $\left(K_{13}\right)$ & -0.741172 & -5.241819 \\
Capital $\left(K_{2}\right)$ & -0.197278 & -0.961307 \\
Labour $(L)$ & 2.174711 & 1.654497 \\
$F$-statistic & 59.36894 & \\
Prob $(F$-statistic) & 0.000763 & \\
$R^{2}$ & 0.99 & \\
\hline
\end{tabular}

*statistically significant at $5 \%$ level of.

gas, placing her third behind Algeria with 78.0 billion cubic metres and Egypt with about 61.3 billion cubic metres. Indeed, a similar conclusion was drawn by [59] who concluded that "...gas production in Nigeria at this current state is not economically or socially worthwhile. That is, it is not profitable to the society." While this may sound absurd, it should be seen more from the inability to put gas produced to productive use, and less from the volume of gas produced.

\section{Conclusion and Recommendations}

The practice of flaring gas and its implication(s) on Nigeria's economic growth and stability has been considered within the traditional resource management viewpoint. The study has been empirically underpinned using a multiple linear regression analysis which established that gas production and flaring impact negatively on the economic growth of Nigeria, thus corroborating the "resource curse" arguments. In the light of this outcome, there is a need to turn this threat/weakness (gas flaring) and opportunity (gas production) into an economic strength.

In the light of the above findings, there is a need to improve on the gas production capacity of Nigeria, while reducing the volume of gas flared to its barest minimum. Consequently, the Federal Government of Nigeria, through its organs and agents, is advised to:

1) Construct more reservoirs suitable for gas re-injection and storage.

2) Expand local and regional gas networks, so as to facilitate improved local consumption of gas produced.

3) Establish adequate fiscal/gas pricing policies as a way of improving/encouraging investments in the gas sub-sector of the oil and gas market.

4) Strengthen existing legal framework so that it could be at par with international standards; Specifically, there is need to re-visit the existing punishment pre- 
scribed for indiscriminate gas flaring and other associated practices in the oil and gas industry as these have not been effective.

\section{REFERENCES}

[1] K. L. Karl, "The Paradox of Plenty: Oil Booms and PetroStates," University of California Press, Berkeley, 1997.

[2] M. L. Ross, "The Political Economy of the Resource Curse," World Politics, Vol. 51, No. 2, 1999, pp. 297-322. doi:10.1017/S0043887100008200

[3] G. Nankani, "Development Problems in Nonfuel Mineral Exporting Countries," Finance and Development, Vol. 17, No. 1, 1980, pp. 6-10.

[4] J. D. Sachs and A. M. Warner, "Natural Resource Abundance and Economic Growth," NBER Working Paper No. 5398, 1997.

[5] D. Wheeler, "Sources of Stagnation in Sub-Saharan Africa," World Development, Vol. 12, No. 1, 1984, pp. 1-23. doi:10.1016/0305-750X(84)90033-0

[6] R. Prebisch, "The Economic Development of Latin America and Its Principal Problems," Lake Success, New York, 1950.

[7] H. W. Singer, "The Distribution of Gains between Investing and Borrowing Countries," American Economic Review, Papers and Proceedings, Vol. 40, No. 2, 1950, pp. 473-485.

[8] R. Nurske, "Trade Fluctuations and Buffer Policies of Low-Income Countries," Kyklos, Vol. 11, No. 2, 1958, pp. 141-154. doi:10.1111/j.1467-6435.1958.tb02361.x

[9] A. O. Hirschman, "The Strategy of Economic Development," Yale University Press, New Haven, 1958.

[10] R. E. Baldwin, "Economic Development and Expert Growth: A Study of Northern Rhodesia, 1920-1960," University of California Press, Berkeley, 1966.

[11] W. Reno, "Corruption and State Politics in Sierra Leone," Cambridge University Press, New York, 1995.

[12] Nigerian National Petroleum Corporation, "Gas Production," Nigerian National Petroleum Corporation. http://www.nnpcgroup.com/NNPCBusiness/UpstreamVe ntures/GasProduction.aspx

[13] E. Ugwuanyi, "Need to Optimise Utilisation of Flared Gas, THE NATION. Energy Section," Vintage Press Ltd., Lagos, 2013, p. 47.

[14] US Energy Information Administration, International, "Energy Statistics," Department of Energy, Washington DC, 2010.

[15] International Energy Agency, "The World Energy Outlook," 2009.

[16] R. L. Daft, "Organization Theory and Design," West Publising, New York, 1983.

[17] J. B. Barney, "Organizational Culture: Can It Be a Source of Sustained Competitive Advantage?" Academy of Management Review, Vol. 11, No. 3, 1986, pp. 656-665. doi:10.5465/AMR.1986.4306261

[18] M. E. Porter, "Competitive Strategy," Free Press, New
York, 1980.

[19] M. E. Porter, "The Contributions of Industrial Organization to Strategic Management," Academy of Management Review, Vol. 6, No. 4, 1981, pp. 609-620. doi:10.5465/AMR.1981.4285706

[20] M. E. Porter, "Competitive Advantage," Free Press, New York, 1985.

[21] M. E. Porter, "Why Are Firms Successful," Paper Presented at the Fundamental Issues in Strategy Conference, Napa, 1990.

[22] S. Madueme, "Economic Analysis of Wastages in The Nigerian Gas Industry," International Journal of Engineering Science and Technology, Vol. 2, No. 4, 2010, pp. 618-624.

[23] S. Madueme, "Gas Flaring Activities of Major Oil Companies in Nigeria: An Economic Investigation," International Journal of Engineering Science and Technology, Vol. 2, No. 4, 2010, pp. 610-617.

[24] S. I. Oni and M. A. Oyewo, "Gas Flaring, Transportation and Sustainable Energy Development in the Niger-Delta, Nigeria," Journal of Human Ecology, Vol. 33, No. 1, 2011, pp. 21-28.

[25] A. Osuoka and P. Roderick, "Gas Flaring in Nigeria: A Human Rights, Environmental and Economic Mon- strosity," A Joint Report Written by the Environmental Rights Action/Friends of the Earth, Nigeria and the Climate Justice Programme, Amsterdam, 2005.

[26] BP, “BP Statistical Review of World Energy,” June 2012.

[27] D. Kahforoshan, E. Fatehifar, A. A. Babalou, A. R. Ebrahimin, A. Elkamel and J. S. Ltanmohammadzade, "Modelling and Evaluation of Air Pollution from a Gaseous Flare in an Oil and Gas Processing Area," Paper Presented at WSEAS Conferences, Santander, 2008.

[28] B. Buzcu-Guven, R. Harriss and D. Hertzmark, "Gas Flaring and Venting: Extent, Impacts, and Remedies," Energy Study Working Paper-Energy Market Consequences of an Emerging US Carbon Management Strategy, Rice University, James Baker III Institute for Public Policy, 2010.

[29] M. F. Farina, "Flare Gas Reduction: Recent Global Trends and Policy Considerations," General Electric Company, 2011.

[30] Government Accountability Office, "Natural Gas Flaring and Venting: Opportunities to Improve Data and Reduce Emissions," US Government Accountability Office (GAO), 2008.

[31] C. D. Elvidge, D. Ziskin, K. E. Baugh, B. T. Tuttle, T. Ghosh, D. W. Pack, E. H. Erwin and M. Zhizhin, "A Fifteen Year Record of Global Natural Gas Flaring Derived from Satellite Data," Energies, Vol. 2, No. 3, 2009, pp. 595-622. doi:10.3390/en20300595

[32] GGFR, "Partners Kick off Work Program for 20102012," The News Flare, World Bank-Global Gas Flaring Reduction, Washington DC, 2010.

[33] GGFR, "GGFR Partners Mark 10th Anniversary by Scaling up Flaring Reduction Efforts," The News Flare, World Bank-Global Gas Flaring Reduction, Washington DC, 2012. 
[34] C. D. Elvidge, K. Baugh, M. Zhizhin and F. C. Hsu, "Satellite Data Estimation of Gas Flaring Volumes," NOAA National Geophysical Data Center, 2012.

[35] P. A. O. Odjugo and E. J. Osemwenkhae, "Natural Gas Flaring Affects Microclimate and Reduces Maize (Zea mays) Yield," International Journal of Agriculture \& Biology. Vol. 11, No. 4, 2009, pp. 408-412.

[36] B. S. V. Atevure, "Processes of Oil Production and Environmental Degradation: An Overview," Journal of Environmental Analysis, Vol. 2, No. 1, 2004, pp. 76-85.

[37] O. E. Inyang, "Gas Flaring and the Nigerian Economy," Economic Review, Vol. 14, No. 1, 2007, pp. 25-33.

[38] C. Collins and O. Oshodi, "Improper Abandonment of Oil," Nigerians in America, 2010.

[39] Nigerian National Petroleum Corporation, "2011 Draft Annual Statistical Bulletin," Corporate Planning and Strategy Division, NNPC, 2012.

[40] Total, "Reducing the Flaring of Associated Gas," undated.

[41] B. Omiyi, "Shell Nigeria Corporate Strategy for Ending Gas Flaring," Seminar on Gas Flaring and Poverty Alleviation, Oslo, 18-19 June 2001, pp. 1-13.

[42] M. Watts, "Petro-Violence: Community, Extraction, and Political Ecology of a Mythic Commodity," In: M. Watts and N. Peluso, Eds., Violent Environments, Cornell University Press, Ithaca, 2001, pp. 189-212.

[43] Africa News Service, "Oil Companies and Gas Flaring in Niger Delta,” P.M. News/All Africa Global Media, Lagos, 2003.

[44] GGFR, "Report on Consultations with Stakeholders," Report 1, World Bank-Global Gas Flaring Reduction, Washington DC, 2002.

[45] C. D. Elvidge, K. E. Baugh, B. T. Tuttle, A. T. Howard, D. W. Pack, C. Milesi and E. H. Erwin, "A Twelve Year Record of National and Global Gas Flaring Volumes Estimated Using Satellite Data," Final Report to the World Bank, 2007.

[46] ERA, CJP/FOE, "Gas Flaring in Nigeria: A Human Rights, Environmental and Economic Monstrosity," A Report by the Climate Justice Programme and Environmental Rights Action/Friends of the Earth Nigeria, Amsterdam, 2005.

[47] Energy Sector Management Assistance Program, "African Gas Initiative: Main Report," Joint UNDP/World Bank Energy Sector Management Assistance Programme, 2001.

[48] N. J. Ashton, S. Arnott and O. Douglas, "The Human Ecosystems of the Niger Delta-An Era Handbook," Environmental Rights Action, Lagos, 1999.

[49] The World Bank, "Regulation of Associated Gas Flaring and Venting: A Global Overview and Lessons from International Experience," World Bank-GGFR Report 3, The International Bank for Reconstruction and Development/The World Bank, Washington DC, 2004.

[50] T. Blasing, J. Hand and B. Kimberly, "Monthly Carbon Emissions for Natural Gas Flaring and Cement Manufacture in the United States," Tellus B, Vol. 59, No. 1, 2007, pp. 15-28. doi:10.3402/tellusb.v59i1.16965

[51] B. Manby, "The Price of Oil: Corporate Responsibility and Human Rights Violations in Nigeria's Oil Producing Communities," Human Rights Watch, New York, 1999.

[52] S. Akpan, "The Production and Utilisation of Natural Gas Resources in Nigeria: A Review," The Nigerian Annual International Conference and Exhibition, Abuja, 3-5 August 2009, 3 p. doi:10.2118/128356-MS

[53] R. Hill, J. Moore, D. Boone and C. Randall, "Associated Gas Utilisation with Liquid Recovery," The Offshore Technology Conference, Houston, 6-9 May 1985, 10 p. doi:10.4043/5039-MS

[54] A. Abdulkareem and J. Odigure, "Economic Benefit of Natural Gas Utilisation in Nigeria: A Case Study of the Food Processing Industry," Energy Sources, Vol. 5, No. 1, 2010, pp. 106-114.

[55] C. W. Cobb and P. H. Douglas, "A Theory of Production," American Economic Review, Vol. 18, No. 1, 1928, pp.139-165.

[56] D. Canning, "Infrastructure's Contribution to Aggregate Output," World Bank Policy Research Working Paper No. 2246, World Bank, Washington DC, 1999.

[57] T. A. Oyeniyi, "Fundamental Principles of Econometrics," Cader Publication Ltd., Lagos, 1997.

[58] W. H. Greene, "Econometric Analysis," Prentice Hall, Upper Saddle River, 2008.

[59] O. M. Gabriel, S. D. Kareem, F. Kari, G. M. Alam and O. D. Matuin, "Impact of Gas Industry on Sustainable Economy in Nigeria: Further Estimations through Eview," Journal of Applied Sciences, Vol. 12, No. 21, 2012, pp. 2244-2251. doi:10.3923/jas.2012.2244.2251

[60] National Bureau of Statistics, "Macro-Economic Data: Gross Domestic Product," National Bureau of Statistics, Abuja, 2013

[61] The World Bank, "World Development Indicators: 19602011," The World Bank Group, 2012.

http://databank.worldbank.org/data/views/reports/tablevie w.aspx

[62] Nigerian National Petroleum Corporation, "2009 Annual Statistical Bulletin," Corporate Planning and Strategy Division, NNPC, 2012. 


\section{Appendix 1. Raw Data Used.}

\begin{tabular}{|c|c|c|c|c|c|c|}
\hline Year & $\begin{array}{l}\text { Gross Domestic } \\
\text { Product }^{*}\end{array}$ & $\begin{array}{l}\text { Gross Capital } \\
\text { Formation }^{*}\end{array}$ & Total Labour Force ${ }^{* *}$ & $\begin{array}{l}\text { Gas Produced }^{* * *} \\
\text { (MSCF) }\end{array}$ & $\begin{array}{l}\text { Gas Utilised }^{* * *} \\
\text { (MSCF) }\end{array}$ & $\begin{array}{l}\text { Gas Flared }^{* * *} \\
\text { (MSCF) }\end{array}$ \\
\hline 2010 & $477,532,990,000$ & $5,171,050,000$ & 50280306.59 & $1,828,541,855$ & $983,562,969$ & $844,978,886$ \\
\hline 2009 & $527,576,030,000$ & $3,793,110,000$ & 48851361.02 & $2,082,283,189$ & $1,195,742,993$ & $886,540,196$ \\
\hline 2008 & $561,931,400,000$ & $2,785,200,000$ & $47558,734.52$ & $2,093,628,859$ & $1,282,313,082$ & $811,315,777$ \\
\hline 2007 & $595,821,610,000$ & $2,449,450,000$ & 46221549.94 & $2,182,432,084$ & $1,378,770,261$ & $803,661,823$ \\
\hline 2006 & $634,251,100,000$ & $2,438,120,000$ & 45002451.22 & $2,415,649,041$ & $1,655,960,315$ & $759,688,726$ \\
\hline 2005 & $672,202,550,000$ & $2,021,220,000$ & 43729560.06 & $2,287,547,344$ & $1,668,148,489$ & $619,398,854$ \\
\hline 2004 & $718,977,330,000$ & $1,941,780,000$ & 42561456.66 & $1,837,278,307$ & $1,327,926,402$ & $509,351,905$ \\
\hline 2003 & $776,332,210,000$ & $1,480,700,000$ & 41795634.41 & $2,392,838,898$ & $1,811,270,545$ & $581,568,354$ \\
\hline 2002 & $834,000,830,000$ & $1,282,980,000$ & 40959413.36 & $240,040,288$ & $1,781,370,022$ & $619,032,858$ \\
\hline 2001 & $356,994,260,000$ & $1,149,930,000$ & 40133163.65 & $1,824,683,025$ & $910,835,428^{* * * *}$ & $913,847,597$ \\
\hline
\end{tabular}

Sources of data: $\left.{ }^{*}[60] ;{ }^{* *}[61]\right) ;{ }^{* * *}[39,62] ;{ }^{* * * *}$ Authors' computation.

\section{Appendix 2. Result of Regression.}

\begin{tabular}{|c|c|c|c|c|}
\hline \multicolumn{5}{|c|}{ Dependent Variable: LOG(GDP) } \\
\hline \multicolumn{5}{|c|}{ Method: Least Squares } \\
\hline \multicolumn{5}{|c|}{ Date: $04 / 05 / 13$ Time: $11: 11$} \\
\hline \multicolumn{5}{|c|}{ Sample: 20012010} \\
\hline \multicolumn{5}{|c|}{ Included observations: 10} \\
\hline Variable & Coefficient & Std. Error & $t$-Statistic & Prob. \\
\hline $\mathrm{C}$ & -2.262501 & 15.96155 & -0.141747 & 0.8941 \\
\hline LOG(GCF) & -0.197278 & 0.205218 & -0.961307 & 0.3908 \\
\hline LOG(LAB) & 2.174711 & 1.314424 & 1.654497 & 0.1734 \\
\hline LOG(GASP) & -0.072858 & 0.022837 & -3.190343 & 0.0332 \\
\hline LOG(GASU) & 0.569982 & 0.099351 & 5.737055 & 0.0046 \\
\hline LOG(GASF) & -0.741172 & 0.141396 & -5.241819 & 0.0063 \\
\hline R-squared & 0.986704 & \multicolumn{2}{|c|}{ Mean dependent var } & 27.11903 \\
\hline Adjusted R-squared & 0.970084 & \multicolumn{2}{|c|}{ S.D. dependent var } & 0.250804 \\
\hline S.E. of regression & 0.043379 & \multicolumn{2}{|c|}{ Akaike info criterion } & -3.153952 \\
\hline Sum squared resid & 0.007527 & \multicolumn{2}{|c|}{ Schwarz criterion } & -2.972401 \\
\hline Log likelihood & 21.76976 & \multicolumn{2}{|c|}{$F$-statistic } & 59.36894 \\
\hline Durbin-Watson stat & 2.672549 & \multicolumn{2}{|c|}{$\operatorname{Prob}(F$-statistic) } & 0.000763 \\
\hline
\end{tabular}

